\title{
APPLICATION OF Zr-Si-B ELECTRODES FOR ELECTROSPARK ALLOYING OF INCONEL 718 IN VACUUM, ARGON AND AIR ENVIRONMENT
}

\author{
A. E. Kudryashov ${ }^{1}$, Ph. V. Kiryukhantsev-Korneev ${ }^{1}$, M. I. Petrzhik ${ }^{1}$, E. A. Levashov ${ }^{1}$ \\ ${ }^{1}$ National University of Science and Technology “MISiS” (Moscow, Russia)
}

E-mail: aekudr@yandex.ru; kiruhancev-korneev@yandex.ru

\section{AUTHOR'S INFO}

\section{A. E. Kudryashov, Cand. Eng., Leading Researcher, Scientific-Educational Center of SHS MISiS-ISMAN, \\ Ph. B. Kiryukhantsev-Korneev, Cand. Eng., Associate Prof., Department of Powder Metallurgy and Functional Coatings; Leading Researcher, Scientific-Educational Center of SHS MISiS-ISMAN, \\ M. I. Petrzhik, Dr. Eng., Prof., Scientific- Educational Center of SHS MISiS-ISMAN, E. A. Levashov, Dr. Eng., Prof., Head of the Department of Powder Metallurgy and Functional Coatings; Director, Scientific- Educational Center of SHS MISiS-ISMAN}

\section{Key words:}

coating, electrospark alloying, vacuum, argon, air, nickel-base alloys, electrodes, phase composition, silicides, borides, oxidation resistance.

\author{
A B S T RAC T
}

This study focused on understanding the effect of various media (such as vacuum, argon and air) on the formation, structure, composition and properties of electrospark coatings deposited on the nickel alloy EP 718-ID (an equivalent of Inconel 718). The $\mathrm{ZrB}_{2}-20 \% \mathrm{~S}$ electrodes were produced by self-propagating high-temperature synthesis. A hand tool with a vibrating electrode was used to form the coatings in air or argon, whereas the coatings deposited in vacuum were produced with the help of an automatic tool with a rotating electrode. It was established that when electrospark alloying is carried out in vacuum or argon a consistent weight gain is observed on the cathode, and the resultant coatings are uniform and have minimum drawbacks. Coatings deposited in air are associated with eroded substrate material and a high degree of imperfection. The coatings deposited on the nickel alloy have a thickness of 20-25 $\mu \mathrm{m}$, a hardness of 12.6-18.8 GPa, and a Young modulus of 237.8-351.4 GPa The roughness of the coatings is $5.8-7.4 \mu \mathrm{m}$. The coatings deposited in argon and in vacuum were found to have the maximum hardness and Young modulus. The following compounds dominate in coatings depending on the medium: zirconium diboride $\mathrm{ZrB}_{2}$ for argon, nickel silicide $\mathrm{Ni}_{(1-x)} \mathrm{Si}_{(x)}$ and zirconium diboride $\mathrm{ZrB}_{2}$ for vacuum, and zirconium dioxide $\mathrm{ZrO}_{2}$ and nickel silicide $\mathrm{Ni}_{(1-x)} \mathrm{Si}_{(x)}$ for air. The coatings deposited in vacuum have the maximum oxidation resistance. It is demonstrated that for quality coatings deposited on nickel alloys the electrode materials $\mathrm{Zr}-\mathrm{Si}-\mathrm{B}$ should be used for ESA in argon or vacuum.

\section{Introduction}

Nickel-based heat-resistant materials are widely used in aviation technology, and namely as parts of the hot gas path in gas-turbine engines, which include turbine blades, compressors, and turbine discs [1]. Heat-resistant nickel alloys find application in nuclear and glass industries [2]. The most effective method to extend the life of heat-resistant alloys is to apply protective coatings [3]. The use of coatings also help save the rare metals (such as Co) that are used in the materials for gas turbines. This is achieved by replacing $\mathrm{Co}$ with $\mathrm{Ni}$ in both the substrate material and coatings [4].

The deposition techniques applicable to heat-resistant nickel alloys can be divided into techniques that rely on thermodiffusion and those that are diffusionless [5]. Advanced diffusionless techniques, which use concentrated energy flows, include magnetron sputtering [6-9] and electrospark alloying [10-37]. The advantages offered by electrospark alloying include high adhesion, the possibility of localized surface treatment, relatively simple implementation, less stricter requirements to surface finish, high reliability of the equipment $[12,20,21]$. The actual deposition process is environmentally friendly and power efficient.

Electrospark alloying is successfully used to protect nickel alloys from oxidation [15, 20-23]. Electrospark alloying of the nickel alloy $\mathrm{ZhS6U}$ with the $\mathrm{CoCrNb}$ electrode helps improve its wear resistance, hardness and heat resistance (at $1000{ }^{\circ} \mathrm{C}$ ) and lower the friction coefficient [15]. Electrospark alloying of the heat-resistant nickel alloy EP 718-ID (Inconel 718) with the Cr-Al$\mathrm{Si}-\mathrm{B}$ electrodes also helps improve hardness, heat and wear resistance of the alloy [20]. The paper [21] demonstrates the potential applicability of the $\mathrm{Mo}-\mathrm{Si}-\mathrm{B}$ electrodes to the nickel alloy EP 718-ID (Inconel 718).

For heat-resistant materials, it would be interesting to consider zirconium diboride $\left(\mathrm{ZrB}_{2}\right)$ and composite ceramics created on its basis, both of which can operate at $1700^{\circ} \mathrm{C}$ for extended periods of time [38]. For enhanced heat resistance and strength of such ceramics, they dope it with various disilicides (primarily with $\mathrm{ZrSi}_{2}$ ), which can form an intercrystalline liquid phase at the $\mathrm{ZrB}_{2}$ grain boundary during alloying, which, in turn, drives down the temperature of the synthesis and makes the material denser [39].

Earlier, the $\mathrm{Zr}-\mathrm{Si}-\mathrm{B}$ ceramics produced by selfpropagating high-temperature synthesis (SHS) was successfully tested for use in coatings with heat resistance reaching $1500^{\circ} \mathrm{C}[9]$ obtained by magnetron sputtering. However, the use of such materials as electrodes for electrospark alloying has not been studied yet.

One important factor governing the phase composition, structure and properties of the coatings installed by electrospark alloying includes the composition of the interelectrode medium [40].

This study aimed to understand the effect of the treatment medium (such as air, argon and vacuum) on the 


\begin{tabular}{|l|c|c|c|c|c|c|c|c|c|}
\hline \multicolumn{2}{|c|}{ Table 1. Properties of electrospark deposited coatings and the substrate } \\
\hline Specimen & Medium & Intermediate Layer & $\sum \Delta a_{10}, 10^{-4} \mathrm{~cm}^{3}$ & $\sum \Delta k_{10}, 10^{-4} \mathrm{~cm}^{3}$ & $\delta, \mu \mathrm{m}$ & $\mathrm{Ra}, \mu \mathrm{m}$ & $H, \mathrm{GPa}$ & $E, \mathrm{GPa}$ & Friction Coefficient \\
\hline 1 & Vacuum & - & -38.00 & 5.63 & 20 & 6.44 & 15.2 & 317.6 & 0.76 \\
\hline 2 & Argon & - & -43.43 & 10.01 & 25 & 5.80 & 18.8 & 351.4 & 0.79 \\
\hline 3 & Air & - & -27.53 & -30.65 & 20 & 7.38 & 12.6 & 237.8 & 0.65 \\
\hline 4 & Air & CCCM & -27.18 & -19.38 & 20 & 6.01 & 14.6 & 248.0 & 0.62 \\
\hline Inconel 718 & - & - & - & - & & 0.40 & 6.4 & 224.6 & 0.31 \\
\hline
\end{tabular}

formation, structure, composition and properties of electrospark coatings deposited on the nickel alloy EP 718-ID (Inconel 718) with SHS Zr-Si-B electrodes.

\section{Materials and Study Techniques}

The consumable electrode (anode) $\mathrm{ZrB}_{2}-6 \% \mathrm{Si}-$ $26 \% \mathrm{ZrSi}_{2}-2 \% \mathrm{ZrO}_{2}$ was produced by $\mathrm{SHS}$ compacting [39] with the following powder composition used: $64.7 \mathrm{Zr}-$ 20Si-15.3B. The electrode had the density of $4.6 \mathrm{~g} / \mathrm{cm}^{3}$, the porosity of $2.7 \%$ and the hardness of $14 \mathrm{GPa}$. Plates of the heat resistant alloy EP 718-ID (Inconel 718) were used as substrates (cathodes).

The electrospark alloying was carried out in different media (air, argon and vacuum) with the help of the industrial unit Alier 303 Metal. The coatings deposited in air and in the Ar medium under normal conditions were installed with a hand tool with the vibration frequency of $600 \mathrm{~Hz}$, whereas the coatings deposited in vacuum (the residual pressure of $10 \mathrm{~Pa}$ ) were installed with a tailored automatic tool with a rotating electrode (0-100 RPS) with $3 \mathrm{D}$ travel control (the travel rate is $50-1000 \mathrm{~mm} / \mathrm{min}$ ) housed in the vacuum chamber UVN-2M [41]. The following machining regime was applied: current strength $I=120 \mathrm{~A}$, impulse frequency $\mathrm{f}=3,200 \mathrm{~Hz}$, duration $\tau=20 \mu \mathrm{s}$. This is an optimum regime for the nickel alloy Inconel 718 and the SHS Cr-Al-B-Si and Mo-Si-B electrodes [20, 21]. The application of the high-frequency regime helps reduce the roughness and increase the thickness and uniformity of coatings [42].

In one case, a carbon-carbon composite material (CCCM) was applied during electrospark alloying of the substrate to build chromium and iron carbides in the surface layer before the substrate was subjected to treatment in air.

The mass transfer kinetics (i.e. specific erosion of the anode $\Delta \mathrm{a}$ and specific weight gain of the cathode $\Delta \mathrm{K}$ ) was analysed on the scale KERN 770 with the accuracy of $10^{-5} \mathrm{~g}$. The total weight gain of the cathode $\left(\Sigma \Delta k_{10}\right)$ and the total erosion of the anode $\left(\sum \Delta a_{10}\right)$ were calculated with the help of the following formulas: [20, 21].

The thickness, uniformity and microstructure were analysed on the Neophot-32 and Hitachi S-3400N SEM microscopes equipped with the energy dispersive X-ray spectrometer NORAN. The X-ray phase analysis of the coatings was performed on the diffractometer DRON-4 with $\mathrm{Cu}-\mathrm{K} \alpha$ radiation. The hardness $(H)$ and the Young modulus $(E)$ were analysed with the help of Nano Hardness Tester by CSM Instruments (Switzerland) at $10 \mathrm{mN}$ [7].

Heat resistance tests were carried out in the SNOL $7.2 / 1200$ electric furnace at $900{ }^{\circ} \mathrm{C}$ with the soaking time of 5 hours. The thickness of the oxidized layer in the specimens was determined through glow discharge optical emission spectroscopy on Profiler 2 HJY [43].

The pin-on-disk tribological test was carried out on a High-temperature Tribometer by CSM Instruments: $\mathrm{Al}_{2} \mathrm{O}_{3} \varnothing 6 \mathrm{~mm}$ ball, linear velocity $10 \mathrm{~cm} / \mathrm{sec}$, load 1 $\mathrm{N}$, temperature $700{ }^{\circ} \mathrm{C}$. The wear tracks and roughness ( Ra stands for the arithmetic mean deviation of the profile) were analysed on the optical profilometer Veeco WYKONT NT 1100.

\section{Results and Discussion}

The weight of the cathode was found to be reducing during electrospark alloying conducted in air. Prior machining of the nickel alloy with a CCCM electrode helps reduce the weight loss (erosion) of the substrate material. During machining in argon or vacuum, a stable weight gain can be observed on the cathode. The maximum total erosion on the anode $\left(\sum \Delta a 10\right)\left(-43.43 \times 10^{-4}\right) \mathrm{cm}^{3}$ and the maximum total weight gain on the cathode $(\Sigma \Delta k 10)$ $\left(10.01 \times 10^{-4}\right) \mathrm{cm}^{3}$ can be reached after 10 minutes of machining in argon (Table 1). Coatings that form on the substrate surface as a result of electrospark alloying are $100 \%$ uniform, have the thickness $(\delta)$ reaching $25 \mu \mathrm{m}$, the hardness of up to $18.8 \mathrm{GPa}$, the Young modulus reaching $351.4 \mathrm{GPa}$ and the roughness $\mathrm{Ra}=5.8-7.4 \mu \mathrm{m}$ (see Table 1). Coatings that form in oxygen-free media typically have high hardness and Young modulus. It is apparent that electrospark alloying helps raise the hardness of the nickel alloy by 1.9-2.9 times. Machining in argon helps produce coatings that would have maximum thickness $(25 \mu \mathrm{m})$ and minimum roughness. The coatings that form in vacuum would be thinner, which can be attributed to the fact that the surface layer gets scraped with the rotating electrode.

The EP 718-ID (Inconel 718) alloy consists of a nickel-based solid solution with an FCC lattice containing carbides and an intermetallic $\gamma$ '-phase $\mathrm{Ni}_{3}(\mathrm{Al}, \mathrm{Ti})$ coherent with the solid solution [44]. The following phases can be observed in the surface layers after electrospark alloying in argon and in vacuum: $\mathrm{Si}$ (21\% and $7 \%$ accordingly), $\mathrm{ZrB}_{2}(73 \%$ and $43 \%), \mathrm{Ni}_{(1-x)} \mathrm{Si}_{(x)}(2 \%$ and $45 \%)$, and the traces of $\mathrm{Ni}$ ( $2 \%$ and $5 \%$ ) (Table 2). The formation of the silicide phase $\mathrm{Ni}_{(1-x)} \mathrm{Si}_{(x)}$ can be attributed to dissociation of $\mathrm{ZrSi}_{2}$ in the interelectrode gap and interaction between $\mathrm{Si}$ and $\mathrm{Ni}$ (an element of the substrate). The presence of a free $\mathrm{Si}$ in the coating is an advantage because a layer of silicon dioxide $\mathrm{SiO}_{2}$ will form on the surface of a specimen exposed to high temperatures for an extended period of time. Such layer has high hardness and strength. 


\begin{tabular}{|c|c|c|c|c|c|c|}
\hline \multicolumn{7}{|c|}{ Table 2. The phase composition of coating and substrate specimens } \\
\hline Specimen & Phase & Type & Group & $\%$ vol & Weight, $\%$ & Periods, nm \\
\hline No coating & Ni-based solid solution & A1 & cF4 & 100 & 100 & $a=0.3611$ \\
\hline \multirow{4}{*}{1} & $\mathrm{Si}$ & A4 & cF8 & 18 & 7 & $a=0.5434$ \\
\hline & $\mathrm{ZrB} \mathrm{B}_{2}$ & $\mathrm{C} 32$ & hP3 & 42 & 43 & $\begin{array}{l}a=0.3159 \\
c=0.3524\end{array}$ \\
\hline & $\mathrm{Ni}$ & $\mathrm{A} 1$ & cF4 & 3 & 5 & $a=0.3483$ \\
\hline & $\mathrm{Ni}_{(1-\mathrm{x})} \mathrm{Si}_{(\mathrm{x})}$ & $\mathrm{A} 1$ & $\mathrm{cF} 4$ & 37 & 45 & $a=0.3605$ \\
\hline \multirow{4}{*}{2} & $\mathrm{Si}$ & $\mathrm{A} 4$ & cF8 & 42 & 21 & $a=0.5421$ \\
\hline & $\mathrm{Zr} \mathrm{B}{ }_{2}$ & C32 & hP3 & 55 & 73 & $\begin{array}{l}a=0.3162 \\
c=0.3523\end{array}$ \\
\hline & $\mathrm{Ni}$ & $\mathrm{A} 1$ & $\mathrm{cF} 4$ & 1 & 2 & $a=0.3494$ \\
\hline & $\mathrm{Ni}_{(1-x)} \mathrm{Si}_{(x)}$ & $\mathrm{A} 1$ & cF4 & 2 & 4 & $a=0.3600$ \\
\hline \multirow{4}{*}{3} & $\mathrm{Ni}_{(1-x)} \mathrm{Si}_{(x)}$ & $\mathrm{A} 1$ & $\mathrm{cF} 4$ & 31 & 34 & $a=0.3570$ \\
\hline & $\mathrm{ZrO}_{2}$ & $\mathrm{C} 1$ & $\mathrm{cF} 12$ & 43 & 39 & $a=0.5083$ \\
\hline & $\mathrm{Fe}_{2} \mathrm{Si}$ & B2 & $\mathrm{CP} 2$ & 22 & 22 & $a=0.2804$ \\
\hline & $\mathrm{Ni}_{4} \mathrm{~N}$ & $L^{\prime} 1$ & CP5 & 4 & 5 & $a=0.3733$ \\
\hline \multirow{7}{*}{4} & $\mathrm{ZrB}_{2}$ & C32 & hP3 & 4 & 4 & - \\
\hline & $\mathrm{ZrC}$ & B1 & cF8 & 2 & 2 & $a=0.4599$ \\
\hline & $\mathrm{Ni}_{(1-x)} \mathrm{Si}_{(x)}$ & $\mathrm{A} 1$ & cF4 & 24 & 26 & $a=0.3579$ \\
\hline & $\mathrm{ZrO}_{2}$ & C1 & $\mathrm{cF} 12$ & 38 & 36 & $a=0.5089$ \\
\hline & $\mathrm{ZrO}_{2}$ & $\mathrm{C} 43$ & $\mathrm{mP} 12$ & 6 & 5 & - \\
\hline & $\mathrm{Fe}_{2} \mathrm{Si}$ & B2 & $\mathrm{cP} 2$ & 21 & 21 & $a=0.2812$ \\
\hline & $\mathrm{Ni}_{4} \mathrm{~N}$ & $\mathrm{~L}^{\prime} 1$ & CP5 & 5 & 6 & $a=0.3738$ \\
\hline
\end{tabular}

conium diboride and zirconium carbide (4 and 2\%, respectively). The presence of $\mathrm{ZrO}_{2}$ indicates that $\mathrm{ZrB}_{2}$ and $\mathrm{ZrSi}_{2}$ decomposed during electrospark alloying when zirconium came in contact with oxygen. The presence of $\mathrm{Ni}_{4} \mathrm{~N}$ is a sign that the coating was formed at high temperatures as there is no reaction between nickel and nitrogen until the temperature has reached $1400^{\circ} \mathrm{C}$ [45].

Coatings deposited in oxygen-free media are more uniform and have less defects (being more solid) compared with coatings produced in air (Fig. 1).

Table 3 contains the results of electron microprobe analysis conducted for surface layers, and Table 4 shows the analysis data obtained for the coatings (specimens). The elements that are predominantly observed in the lighter region in the surface layers of the coatings deposited in oxygen-free media include elements of the substrate $(\mathrm{Ni}, \mathrm{Fe}, \mathrm{Cr})$ $($ Fig. $1 \boldsymbol{a}, \boldsymbol{c}, \boldsymbol{e})$. The dark region has high concentrations of $\mathrm{Zr}$ and $\mathrm{Si}$, the elements of the electrode material. Three separate

The following phases were found in the coating during machining in air: $\mathrm{Ni}_{(1-x)} \mathrm{Si}_{(x)}-34 \%, \mathrm{ZrO}_{2}-39 \%$, $\mathrm{Fe}_{2} \mathrm{Si}-22 \%$ and the traces (5\%) of nickel nitride $\mathrm{Ni}_{4} \mathrm{~N}$. The following is observed in the coating produced by CCCM machining followed by SHS electrode machining: $\mathrm{Ni}_{(1-x)} \mathrm{Si}_{(x)} 26 \%$, zirconium dioxide (two structural types) $-41 \%, \mathrm{Fe}_{2} \mathrm{Si}-21 \%, \mathrm{Ni}_{4} \mathrm{~N}(6 \%)$ and traces of zir- regions with oxygen are observed in specimens produced in air. Elements of the substrate material dominate in the light region, with the amount of oxygen being minimal $-3.1 \%$. Compared with the light region, the dark region has the highest concentration of oxygen i.e. $30.3 \%$, and a high concentration of $\mathrm{Si}$. High concentrations of oxygen $(26.6 \%)$ and zirconium $(20.0 \%)$ are observed in the

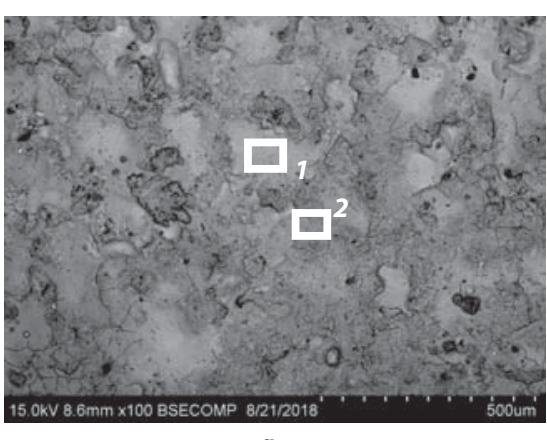

a

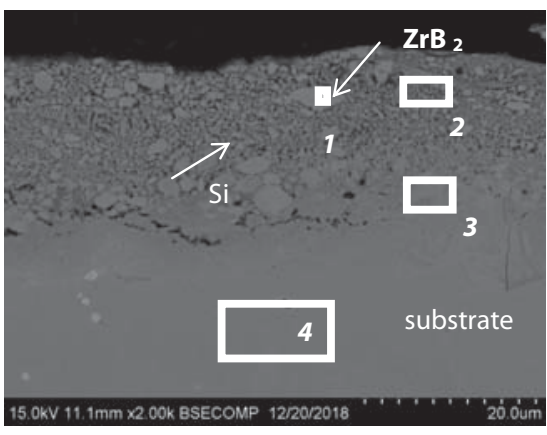

$d$

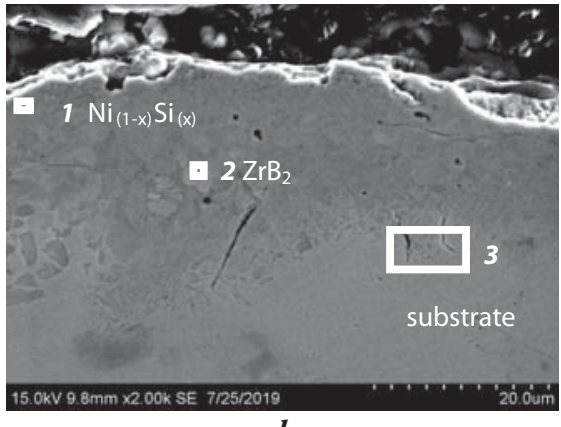

b

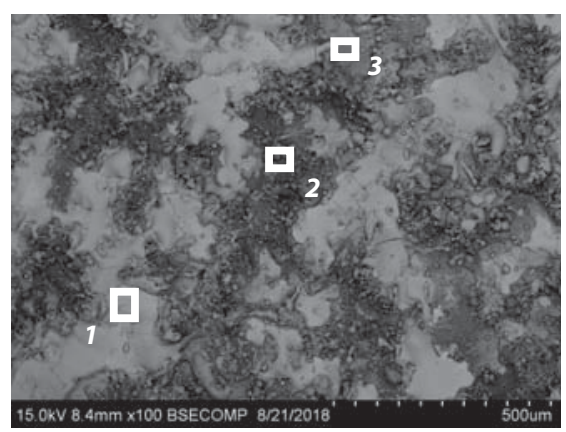

e
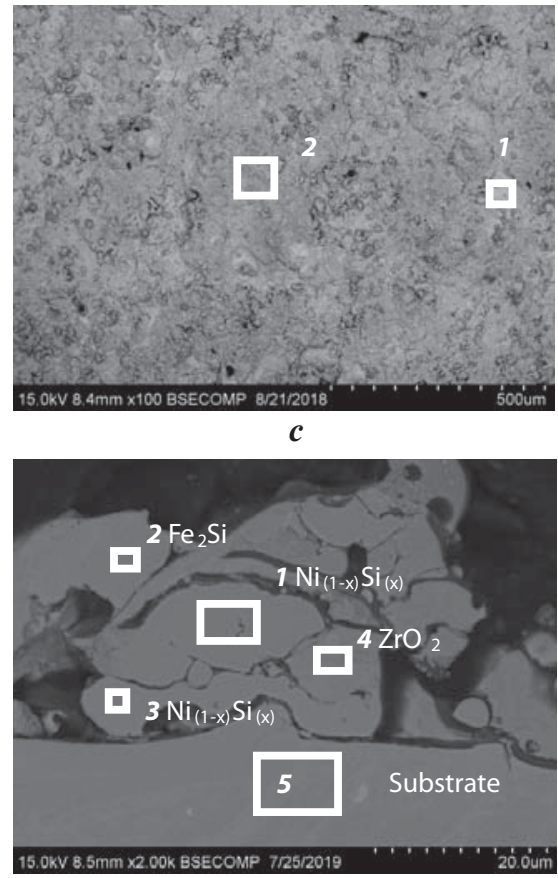

$f$

Fig. 1. Coating structure. Plan-view $(a, c, e)$ and cross-sectional $(b, d, f)$ imaging: $a, b-$ Specimen $1 ; c, d-$ Specimen $2 ; e, f-$ Specimen 3 
grey region 3 suggesting that this region may contain zirconium dioxide $\mathrm{ZrO}_{2}$. Carbon can be found in the surface layer of the coatings installed on the substrate that had been pre-machined with CCCM.

The coating (specimens) produced in vacuum consists of $\mathrm{ZrB}_{2}$ grains with $\mathrm{Ni}_{(1-x)} \mathrm{Si}_{(\mathrm{x})}$ between them (Fig. 1, b). The structure of the coating produced

\begin{tabular}{|c|c|c|c|c|c|c|c|c|c|c|}
\hline \multicolumn{10}{|c|}{ Table 3. Surface layer composition (wt. \%) according to plan-view imaging (Fig. 1 a, c, e) } \\
\hline \multirow{2}{*}{ Specimen } & Region & Al-K & Si-K & Ti-K & Cr-K & Fe-K & Ni-K & Zr-L & $\begin{array}{c}\text { Mo-L } \\
(\mathrm{Mn}-\mathrm{K})\end{array}$ & O-K \\
\hline \multirow{2}{*}{1} & 1 & 1.0 & 8.1 & 2.2 & 13.5 & 22.8 & 39.0 & 9.9 & 3.6 & - \\
\cline { 2 - 13 } & 2 & 0.4 & 16.4 & 1.4 & 8.1 & 14.5 & 25.7 & 33.4 & - & - \\
\hline \multirow{2}{*}{2} & 1 & 0.6 & 15.5 & 1.4 & 8.4 & 15.9 & 28.1 & 30.1 & - & - \\
\cline { 2 - 12 } & 2 & 0.2 & 28.9 & 0.5 & 2.8 & 8.1 & 11.1 & 48.1 & $(0.3)$ & - \\
\hline \multirow{3}{*}{3} & 1 & 0.7 & 8.1 & 1.8 & 13.4 & 24.1 & 40.5 & 4.8 & - & 3.1 \\
\cline { 2 - 11 } & 2 & 1.5 & 12.6 & 1.0 & 9.5 & 15.5 & 23.8 & 4.5 & - & 30.3 \\
\cline { 2 - 10 } & 3 & 1.5 & 8.8 & 1.4 & 8.2 & 13.2 & 20.2 & 20.0 & - & 26.6 \\
\hline
\end{tabular}

\begin{tabular}{|c|c|c|c|c|c|c|c|c|c|c|c|c|c|}
\hline Specimen & Region & O-K & $\mathrm{C}-\mathrm{K}$ & $\mathrm{B}-\mathrm{K}$ & $\mathrm{Al}-\mathrm{K}$ & $\mathrm{Si}-\mathrm{K}$ & $\mathrm{Ti}-\mathrm{K}$ & $\mathrm{Cr}-\mathrm{K}$ & Fe-K & $\mathrm{Ni}-\mathrm{K}$ & $\mathrm{Zr}-\mathrm{L}$ & Mo-L & W-M \\
\hline \multirow{3}{*}{1} & 1 & - & - & - & - & 24.5 & 1.1 & 5.7 & 10.4 & 17.2 & 41.2 & - & - \\
\hline & 2 & - & - & 7.0 & - & - & - & - & - & - & 93.0 & - & - \\
\hline & 3 & - & 2.0 & - & 1.2 & 1.6 & 2.6 & 15.5 & 25.6 & 47.3 & & 4.2 & - \\
\hline \multirow{4}{*}{2} & 1 & - & - & 6.9 & - & - & - & - & - & - & 93.1 & - & - \\
\hline & 2 & - & - & 8.9 & - & 21.5 & 0.6 & 1.1 & 1.9 & 2.7 & 63.3 & - & - \\
\hline & 3 & - & - & 12.3 & - & 9.9 & 1.2 & 3.5 & 6.2 & 10.0 & 56.7 & - & - \\
\hline & 4 & - & - & - & 1.3 & - & 2.7 & 16.1 & 26.4 & 45.5 & 0.0 & 3.8 & 4.2 \\
\hline \multirow{5}{*}{3} & 1 & - & 4.4 & - & 0.4 & 8.4 & 1.6 & 14.1 & 23.9 & 42.6 & 1.6 & 3.1 & - \\
\hline & 2 & - & 3.9 & - & 0.4 & 8.7 & 1.7 & 14.2 & 24.1 & 41.6 & 2.6 & 2.7 & - \\
\hline & 3 & - & 4.3 & - & 0.3 & 7.0 & 1.7 & 13.8 & 24.0 & 42.8 & 3.1 & 3.1 & - \\
\hline & 4 & 24.3 & 8.8 & - & 2.8 & 1.4 & 3.4 & 1.4 & - & - & 57.5 & - & - \\
\hline & 5 & - & 3.0 & - & 1.3 & 0.8 & 2.4 & 15.8 & 27.4 & 45.9 & - & 3.5 & - \\
\hline
\end{tabular}

in argon is comprised of $\mathrm{ZrB}_{2}$ grains with layers of Si observed between them (Figure $1 d$ ). A relatively high concentration of elements of the substrate can be observed in the regions $1-3$ of the coating deposited in air (see Fig. 1, $f$ ). A similar structure is observed in the coating that has an intermediate layer.

A solid oxide layer formed on the surface of the specimens following 5 hours of high-temperature soaking. The depth of the oxidized layer was measured with the help of glow discharge optical emission spectroscopy. The etching depth of the coating (thickness) serves as a criterion indicating the oxidation of the surface layer. The oxygen concentration in that layer was 10 at. $\%$. The thickness of the oxidized layer of the substrate was $\sim 4.8 \mu \mathrm{m}$. The maximum thickness of the oxidized layer on the specimen with a coating deposited in air was $1.9 \mu \mathrm{m}$ (Fig. 2).

Deposition of specimens in argon and vacuum produced coatings with the thickness of the oxidized layer being 1.6 and $0.9 \mu \mathrm{m}$, correspondingly. Pre-machining of the nickel specimen before coating it with an SHS alloy using an CCCM electrode resulted in a reduced depth of the oxidized layer, which reduced to $0.93 \mu \mathrm{m}$.

The specimens with electrospark deposited coatings have a smaller depth of the oxidized layer than the nonhardened specimen. Hence, the coatings deposited with the help of the $\mathrm{Zr}-\mathrm{Si}-\mathrm{B}$ electrode material enhance the heat-resistance of nickel alloy.

It was established that the specimen without the nickel alloy coating has the lowest friction coefficient - i.e.
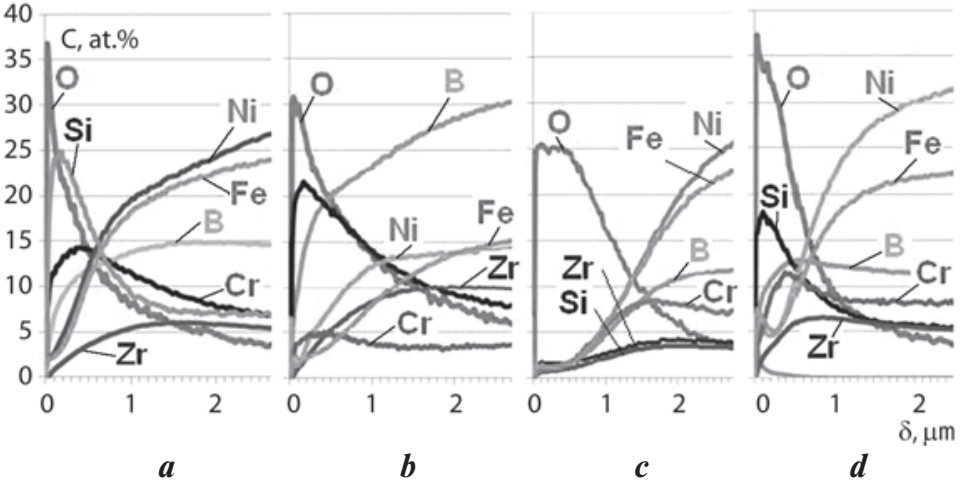

Fig. 2. Distribution of elements in the coatings after high-temperature soaking. Temperature $t=900{ }^{\circ} \mathrm{C}$, duration $\tau=5 \mathrm{~h}$ : $a$-Specimen 1; $b-$ Specimen 2; $c$ - Specimen 3; $d$-Specimen 4

0.31 (see Table 1). The coatings deposited in argon and vacuum were found to have the highest friction coefficients -0.79 and 0.76 , respectively. This can probably be attributed to the domination of zirconium diboride $\mathrm{ZrB}_{2}$ in the surface layers. The researchers were not able to determine the wear resistance of the specimens with electrospark deposited coatings due to developed surface topology and the lack of visible fractures in the coating.

\section{Acknowledgements}

This work was carried out with financial support from the Ministry of Education and Science of the Russian Federation in the framework of state assignment No.11.7172.2017/8.9. The authors would like to thank 


\section{N.V. Shvyndina, T.A. Sviridova, A.N. Sheveiko for their support during the study.}

\section{Conclusions}

1. It was established that the deposition medium influences the mass transfer of the electrode material. A gain in the cathode weight is observed in oxygen-free media, whereas deposition in air is associated with a loss in the cathode weight.

2. The coatings produced by electrospark alloying are $100 \%$ uniform, have the thickness of up to $25 \mu \mathrm{m}$ and the roughness $(\mathrm{Ra})$ of 5.8-7.4 $\mu \mathrm{m}$. The coatings have the hardness within 12.6-18.8 GPa and the Young modulus within 237.8-351.4 GPa. The coatings deposited in argon have the highest hardness and Young modulus.

3. The deposition medium influences the phase composition and the structure of coatings. $\mathrm{ZrB}_{2}$ and $\mathrm{Si}$ were found in coatings obtained in argon. Nickel silicide $\left(\mathrm{Ni}_{(1-x)} \mathrm{Si}_{(x)}\right)$ and $\mathrm{ZrB}_{2}$ were present in coatings produced in vacuum, and $\mathrm{ZrO}_{2}, \mathrm{Ni}_{(1-x)} \mathrm{Si}_{(x)}$ silicides and $\mathrm{Fe}_{2} \mathrm{Si}-$ in coatings installed in air. The coatings deposited in oxygen-free media have better uniformity and less imperfections.

4. Electrospark alloying with the $\mathrm{Zr}-\mathrm{Si}-\mathrm{B}$ electrodes makes the nickel alloy more heat-resistant. The specimen produced in vacuum has the thinnest oxidized layer.

5 . It is recommended to use argon or vacuum for electrospark alloying with the $\mathrm{Zr}-\mathrm{Si}-\mathrm{B}$ electrodes.

\section{REFERENCES}

1. High temperature and wrought alloys for modern and prospective gas turbine engines. Electronic resource: www.viam. ru/public/files/2007/2007-204757.pdf

2. Bazyleva O. A., Arginbaeva E. G., Lutskaya S. A. Raising the corrosion resistance of heat-resistant nickel alloys: A review. Trudy VIAM. 2018. No. 4 (64). pp. 3-8.

3. Poklad V. A., Shkretov Yu. P., Abraimov N. V. Coatings designed to protect turbine rotor blades from high-temperature gas corrosion. Dvigatel. 2010. No. 4 (70). pp. 2-4.

4. Hocking M., Vasantasree V., Sidky P. Metallic and ceramic coatings: Production, properties and applications. Translated from English by Lazarev E. M. et al. Moscow : Mir. 2000. 516 p.

5. Podchernyaeva I. A., Panasyuk A. D., Teplenko M. A., Podolskii V. I. Protective coatings on heat-resistant nickel alloys (review). Powder Metallurgy and Metal Ceramics. 2000. Vol. 39. No. 9-10. pp. 434-444.

6. Kelly P. J., Arnell R. D. Magnetron sputtering: a review of recent developments and applications. Vacuum. 2000 (56). pp. 159-172.

7. Levashov E. A., Shtansky D. V., Kiryukhantsev-Korneev Ph. V., Petrzhik M. I., Tyurina M. Ya., Sheveiko A. N. Multifunctional Nanostructured Coatings: Formation, Structure, and the Uniformity of Measuring Their Mechanical and Tribological Properties. Russian Metallurgy (Metally). 2010. No. 10. pp. 917-935.

8. Kiryukhantsev-Korneev Ph. V., Iatsyuk I. V., Shvindina N. V., Levashov E. A., Shtansky D. V. Comparative investigation of structure, mechanical properties, and oxidation resistance of $\mathrm{Mo}-\mathrm{Si}-\mathrm{B}$ and $\mathrm{Mo}-\mathrm{Al}-\mathrm{Si}-\mathrm{B}$ coatings. Corrosion Science. 2017. (123). pp. 319-327.

9. Kiryukhantsev-Korneev Ph. V., Lemesheva M. V., Shvindina N. V., Levashov E. A., Potanin A. Yu. Structure, Mechanical Properties, and Oxidation Resistance of $\mathrm{ZrB}_{2}, \mathrm{ZrSiB}$, and $\mathrm{ZrSiB} / \mathrm{SiBC}$ Coatings. Protection of Metals and Physical Chemistry of Surfaces. 2018. Vol. 54, No. 6. pp. 1147-1156.

10. Kiryukhantsev-Korneev Ph. V., Sytchenko A. D., Kudryashov A. E., Levashov E. A. Protective coatings produced by electrospark deposition with $\mathrm{TiCNiCr}-\left(\mathrm{Eu}_{2} \mathrm{O}_{3}\right)$ electrodes. CIS Iron and Steel Review. 2018. Vol. 16. pp. 57-62.

11. Kudryashov A. E., Doronin O. N., Zamulaeva E. I., Levashov E. A., Shvindina N. V. Application of SHS electrode materials and technology of electrospark deposition for strengthening of rolling rolls. Chernye Metally. 2013. No. 10. pp. 61-68.

12. Levashov E. A., Kudryashov A. E., Sheveiko A. N., Vakaev P. V., Zamulaeva E. I., Stolin A. M. On successful application of electrospark alloying in metallurgy and mechanical engineering. Tsvetnye Metally. 2003. No. 6. pp. 73-77.

13. Podchernyaeva I. A., Yurechko D. V., Bochko A. V., Sedlyar G. A., Kostenko L. M. Effect of electrospark deposition of $\mathrm{Al}-\mathrm{Si}$ alloy on the wear resistance of a hard-alloy cutting plate. Powder Metallurgy and Metal Ceramics. 2012. Vol. 51. No. 3-4. pp. 198-203.

14. Radek N., Antoszewski K., Bronček J., Fabian P., Pietraszek J. Properties of the electro-spark deposited coatings - technology and applications. Materials Science Forum. 2015. (818). pp. 61-64.

15. Levashov E. A., Kudryashov A. E., Zamulaeva E. I., Pogozhev Yu. S., Sanin V. N., Andreev D. E., Yukhvid V. I. Features of Formation and the Structure, Composition, and Properties of Electrospark Coatings on the ZhS6U Nickel Alloy with the Use of the KhTN-61 SHS-Ts Alloy. Russian Journal of Non-Ferrous Metals. 2009. Vol. 50. No. 5. pp. 534-539.

16. Nikolenko S. V., Syuy N. A., Burkov A. A. Investigation of microstructure and properties of coatings on the steel 45, applied by $\mathrm{TiC}-\mathrm{Ni}-\mathrm{Mo}$ based electric discharge deposition. Tsvetnye Metally. 2017. No. 4. pp. 69-75.

17. Burkov A. A., Kulik M. A., Krutikova V. O. Characteristics of Ti-Si Coatings on Ti6Al4V Alloy Subjected to Electrospark Granules Deposition. Tsvetnye Metally. 2019. No. 4. pp. 54-59.

18. Pyachin S. A., Burkov A. A. Nitridation of titanium surface by electric charge treatment. Tsvetnye Metally. 2017. No. 4. pp. 62-68.

19. Shtansky D. V., Batenina I. V., Yadroitsev I. A. et al. A new combined approach to metal-ceramic implants with controllable surface topography, chemistry, blind porosity, and wettability. Surface \& Coatings Technology. 2012. (208). pp. 14-23.

20. Kudryashov A. E., Lebedev D. N., Potanin A. Yu., Shvyndina N. V., Sukhorukova I. V., Shtanskiy D. V., Levashov E. A. Deposition kinetics, structure and properties of electrospark deposited $\mathrm{Cr}-\mathrm{Al}-\mathrm{Si}-\mathrm{B}$ coatings installed on heat-resistant nickel alloy. Izvestiya vuzov. Poroshkovaya metallurgiya i funktsionalnye pokrytiya. 2015. No. 4. pp. 59-70.

21. Kudryashov A. E., Lebedev D. N., Potanin A. Yu., Levashov E. A. Structure and properties of coatings produced by pulsed electrospark deposition on nickel alloy using $\mathrm{Mo}-\mathrm{Si}-\mathrm{B}$ electrodes. Surface and Coatings Technology. 2018. Vol. 335. pp. 104-117. 
22. Ebrahimnia M. F., Ghaini M., Xie Y. J., Shahverdi H. Microstructural characteristics of the built up layer of a precipitation hardened nickel based superalloy by electrospark deposition. Surface \& Coatings Technology. 2014. (258). pp. 515-523.

23. Yu-jiang Xie, Mao-cai Wang. Epitaxial MCrAlY coating on a Ni-base superalloy produced by electrospark deposition. Surface \& Coatings Technology. 2006 (201). pp. 3564-3570.

24. Enrique P. D., Jiao Z., Zhou N. Y., Toyserkani E. Dendritic coarsening model for rapid solidification of $\mathrm{Ni}$-superalloy via electrospark deposition. Journal of Materials Processing Technology. 2018. Vol. 258. pp. 138-143.

25. Wang D., Wang W., Wang M. et al. Effect of operating voltage on microstructure and microhardness of NiCoCrAlYTa$\mathrm{Y}_{2} \mathrm{O}_{3}$ composite coatings on single crystal superalloy produced by electrospark deposition. Surface and Coatings Technology. 2019. Vol. 358. pp. 628-636.

26. Xie Y., Wang D., Wang M., Ye W. Evaluation of three kinds of MCrAlY coatings produced by electrospark deposition. Transactions of Nonferrous Metals Society of China. 2016. (26). p. 1647.

27. Cao G., Wang Y., Tang G. Properties of NiCrAlY coatings fabricated on superalloy GH4169 by electrospark deposition. The International Journal of Advanced Manufacturing Technology. 2018. Vol. 96, Issue 5-8. pp. 1787-1793.

28. Ribalko A. V., Sahin O., Korkmaz K. A modified electrospark alloying method for low surface roughness. Surface and Coatings Technology. 2009. Vol. 203, Iss. 23. pp. 3509-3515.

29. Korkmaz K. Investigation and characterization of electrospark deposited chromium carbide-based coating on the steel. Surface and Coatings Technology. 2015. Vol. 272. pp. 1-7.

30. Luo C., Dong S., Xiong X., Zhou N. Mass loss of copper alloy electrode during $\mathrm{TiB}_{2}$ coating by electrospark deposition. Surface and Coatings Technology. 2009. (203). pp. 3333-3337.

31. Johnson R. N., Sheldon G. L. Advances in the electrospark deposition coating process. Journal of Vacuum Science \& Technology A: Vacuum, Surfaces and Films. 1986. pp. 2740-2746.

32. Kuptsov S. G., Fominykh M. V., Mukhinov D. V., Magomedova R. S., Nikonenko E. A. Electrospark alloying of the AL9 alloy with hard alloys. Rasplavy. 2015. No. 4. pp. 90-94.

33. Verkhoturov A. D., Konevtsov L. A., Shpilev A. M. et al. Contribution of electrospark alloying to the oxidation resistance of hard tungsten alloys. Powder Metallurgy and Metal Ceramics. 2008. Vol. 47, No. 1-2. pp. 112-115.

34. Ageeva E. V., Latypov R. A., Ageev E. V., Altukhov A. Yu., Karpenko V. Yu. Characteristics of electrospark deposited coatings produced with electrodes made of high-speed steel powders. Izvestiya vuzov. Poroshkovaya metallurgiya i funktsionalnye pokrytiya. 2015. No. 2. pp. 62-65.
35. Astapov I. A., Eremina K. P., Teslina M. A. et al. Structure and properties of functional coatings electrospark deposited on $20 \mathrm{Kh} 13$ steel. Obrabotka Metallov (tekhnologiya, oborudovanie, instrumenty). 2013. No. 4 (61). pp. 12-18.

36. Podchernyaeva I. A., Verkhoturov A. D., Vostrikov Ya. A., Konevstov L. A. Deposition and properties of composite coatings installed by electrospark alloying on ShKh15 and R6M5 steels using new ceramic materials. Uprochnyayushchie tekhnologii i pokrytiya. 2015. No. 2(122). pp. 34-39.

37. Gitlevich A. E., Mikhaylov V. V., Parkanskiy N. Ya. et al. Electrospark alloying of metallic surfaces. Kishinev : Shtiintsa, $1985.195 \mathrm{p}$.

38. Grigoriev O. N., Frolov G. A., Evdokimenko Yu. I., Kisel V. M., Panasyuk A. D., Melakh L. M., Kotenko V. A., Koroteev A. V. Ultrahigh-temperature ceramics for aerospace engineering. Aviatsionno-kosmicheskaya tekhnika i tekhnologiya. 2012. No. 8(95). pp. 119-128.

39. Pogozhev Yu. S., Iatsyuk I. V., Potanin A. Yu. et al. The kinetics and mechanism of combusted Zr-B-Si mixtures and structural features of ceramics based on zirconium boride and silicide. Ceramics International. 2016. Vol. 42. pp. 16758-1676.

40. Mikhailov V. V., Gitlevich A. E., Verkhoturov A. D., Mikhailyuk A. I., Belyakov A. V., Konevtsov L. A. Electrospark alloying of titanium and its alloys: the physical, technological, and practical aspects. Part 1. The peculiarities of the mass transfer and the structural and phase transformations in the surface layers and their wear and heat resistance. Surface Engineering and Applied Electrochemistry. 2013. Vol. 49. No. 5. pp. 373-395.

41. Sheveyko A. N., Kuptsov K.A., Kiryukhantsev-Korneev Ph. V., Levashov E. A., Shtansky D. V. Hybrid Technology Combining Vacuum Electrospark Alloying, Cathodic Arc Evaporation and Magnetron Sputtering for the Deposition of Hard-Wear Resistant Coatings. Russian Journal of Non-Ferrous Metals. 2019. Vol. 60, No. 5, pp. 598-607.

42. Safronov I. I., Tsurkan I. V., Fateev V. V., Semenchyuk A. V. Electroerosion processes on electrodes and the microstructural and phase composition of the alloyed layer. Chisinau: Stiinta, 1999. $591 \mathrm{p}$.

43. Kiryukhantsev-Korneev F. V. Possibilities of Glow Discharge Optical Emission Spectroscopy in the Investigation of Coatings. Russian Journal of Non-Ferrous Metals. 2014. Vol. 55. No. 5. pp. 494-504.

44. Sorokin L. I. Weldability of heat-resistant alloys finding application in aircraft gas turbine engines. Svarochnoe proizvodstvo. 1997. No. 4. pp. 1-21.

45. Drits M. E. Properties of the elements - Reference book. Metallurgiya, $1985.672 \mathrm{p}$. 